\title{
"This Is Where I Want To Be:" Pedagogical and Integrative Practices of African American Learning Communities and Their Impact on Students
}

Tess Hansen, Ed.D. Foothill College

\begin{abstract}
This qualitative study explores pedagogical practices and student responses in three community college learning communities targeting African American students. Using classroom observations, instructor and student interviews, and student focus groups, the study examines how instructors teach in race-based programs and how students respond to these pedagogies. The study uses a conceptual model that integrates retention theory, critical race theory, and integration of instruction and student services theory.

The study finds that culturally responsive pedagogical and classroom management
\end{abstract}

techniques result in enhanced student perceptions of themselves as capable learners. Students also report developing a sense of African American identity through the experience of the curriculum and the racially homogeneous community of learners.

This research has implications for policy and practice at community colleges by providing evidence that race-based programs are crucial for the academic and social integration of African American students into academia. The study also recommends that structural changes be made to community college practice, including integrating the role of student service professionals into curriculum design.
The issue of educational achievement of African Americans has been, and continues to be, a persistent problem within all segments of the American educational system. Table 1 is a snapshot of the ways in which African American students lag behind their white, Asian, and Latino counterparts in significant ways.

In general, what the above statistics show is that African American students perform in both secondary and higher education at rates much lower than their white, Asian, and Latino counterparts. When looking at bachelor's degree completion, $37 \%$ of whites 25 or older have completed a bachelor's degree or higher, and almost $70 \%$ of Asians in this same age group have at least a bachelor's degree. Within the African American population, this number drops significantly, to just $19 \%$ of blacks 25 or older having completed at least a bachelor's degree.

Persistence numbers show that African American college students do not succeed at the same rates as other students. When looking at the students who began in a four-year institution in 2003 and who stayed enrolled (or achieved a degree/certificate) within three years, African American students lag behind their white and Asian counterparts by 10 and 16 percentage points, respectively. The same gap exists for students in two-year institutions where after three years only $47 \%$ of African American students are still enrolled (or have achieved a degree/certificate) in three years, compared to $56 \%$ of white students and $67 \%$ of Asian students.

What all of these statistics point to is a pervasive problem in the American higher educational system 
Table 1

Statistics on African American Educational Achievement (Source: NCES, 2012, except as noted)

\begin{tabular}{lcccc}
\hline $\begin{array}{l}\text { Educational Attainment } \\
\text { Measurement }\end{array}$ & White & $\begin{array}{c}\text { African } \\
\text { American }\end{array}$ & Latino & $\begin{array}{c}\text { Asian/ } \\
\text { Pacific Isander }\end{array}$ \\
\hline High school graduation $^{1}$ & 81 & 63 & 65 & 90 \\
Enrollment in college $^{2}$ & 74 & 62 & 58 & 85 \\
Bacherlor's degree completion $^{3}$ & 62 & 38 & 50 & 69 \\
Bacherlor's degree attainment $^{4}$ & 37 & 19 & 13 & 62 \\
Persistence in college-4-year institutions $^{5}$ & 83 & 73 & 76 & 89 \\
Persistence in college-2-year institutions $^{5}$ & 56 & 47 & 54 & 67 \\
Taking remedial courses $^{6}$ & 31.3 & 45.1 & 43.3 & 38 \\
& & & & \\
\hline
\end{tabular}

${ }^{1}$ Average freshman graduation rate from 2008-09

2 Percentage of 2004 high school graduates immediately enrolled in a post-secondary institution

${ }^{3}$ Graduation rates of post-secondary students receiving Bachelor's degrees within 6 years (2004 cohort)

${ }^{4}$ Percentage of adults ages 25-34 whose highest educational attainment in a Bachelor's degree

${ }^{5}$ Percentage of students still enrolled or with certificate/degree after three years, 2003 cohort (ACE, 2010)

${ }^{6}$ Percentage of first-year undergraduate students who took any remedial course, 2007-08 cohort (ACE, 2010)

in educating African American students. One promising initiative for African American students is the development of retention programs in community colleges that blend skill improvement, ethnic cultural development, and an array of student support services. Research has identified practices that structure the first year of college activities to improve retention, academic performance and student satisfaction (Engstrom and Tinto, 2007). This study focuses on identifying the pedagogical and integrative practices of successful programs for African American students in the community college system. The results of the study will inform researchers and practitioners on strategies to narrow the achievement gap between African Americans and other ethnicities in higher education.

\section{Purpose of the Study}

This study highlights three community colleges with programs that address African American students' college success, examining the pedagogical and support service practices in these programs so that scholars and practitioners might be aware of alternate teaching and support service strategies that focus on the needs of African American students.
Specifically, the study focuses on the pedagogies and teacher behaviors present in the learning community classrooms and the interactions between instruction and student services within the learning community design. The study employs a qualitative approach in order to illuminate the perceptions and experiences of students and faculty with respect to the pedagogy and student services practices in the learning communities.

In a resource-scarce climate, this study provides suggestions on how the practices of the three programs studied could be broadened to be applied to a larger audience without compromising the essence of such programs. Looking at program components that are scalable may inform educational leaders about practices that they too can employ to increase the success of their students.

\section{Research Questions}

This study addresses the following research questions: (a) what pedagogical practices are present in the classrooms of learning communities designed for African American students?; (b) what are student perceptions of the various pedagogies used in the classrooms?; and (c) to what extent do the learning 
communities integrate instruction and student services?

\section{Conceptual Framework}

The conceptual model of this study is grounded in two theories: retention theory and critical race theory, and the intersection of the two. The earliest retention theoretical construct is found in the work of Tinto (1975) who posits that "academic integration" and "social integration" most influence a student's decision to persist in college. Academic integration occurs when a student connects to the faculty, classroom, and institutional policies in order to establish a bond with the college. Social integration occurs when a student connects to individuals and activities outside the classroom. According to this model, both conditions are necessary to ensure the student's retention in college.

Challenges to Tinto's model have been raised by scholars who critique the model for its failure to take into account the experiences of minority students (Bensimon, 2005; Braxton, et al, 2008; Braxton, Hirschy, \& McClendon, 2004; Guiffrida, 2006; Tierney, 1999). Specifically, Tierney likens Tinto's model to "cultural suicide" (p. 85) in which students divorce themselves from the communities and cultures in which they were raised in order to assimilate to the college culture. Tierney argues that students are more likely to persist in college if their identities are affirmed and incorporated into the college culture.

When discussing the pedagogies most likely to lead to student success, researchers cite authentic pedagogy (Braxton, Jones, Hirschy \& Hartley, 2008; Darling-Hammond, 2008; McHugh Engstrom, 2008) as a key component of student persistence. In her study of community college students and professors, Cox (2009) cites the need for teachers who have high standards and confidence in students' abilities to achieve those high standards.

Moving from retention theory, the study focuses on critical race theory to explore particular needs of African American students in college. This theory sets the foundation for the pedagogical practices that cite the need for culturally responsive pedagogy, the practice that takes critical race theory into the college classroom. Finally, the study uses the integration of instruction and student services as a theoretical grounding, citing the importance of a unified college collaboration to enhance the success of African American students.

Critical race theory is based upon the premise that racism is an everyday ordinary occurrence and is the common shared experience of people of color in this country (Delgado and Stefancic, 2001; Lopez, 2003; Yosso, et al, 2009). According to Delgado and Stefancic (2001), critical race theory had its beginning in law, but is used today in education to understand the issues of "school discipline and hierarchy, tracking, curriculum, and IQ and achievement testing" (p. 3). In a review of critical race theory literature and adult education, Closson (2010) describes the theory in education as the use of race in a systematic analysis of educational inequality. As such, critical race educational theorists are interested in changing the current educational system, to move from disparate educational attainments of students of color to a system that educates all students equally.

Using critical race theory, researchers in higher education are taking educational theorists to task for their failure to account for the experiences of students of color in highly racialized climates (Delgado and Stefancic, 2001; Yosso, 2009). Many educators feel that race is an area that has been under-researched in higher education. Johnson-Bailey \& Lee (2005), however, argue that in fact, we have excellent studies of the way race affects the academic experience of African Americans and the way race can operate in higher education classrooms. Critical race theorists argue that rather than using race as a demographic variable, race and racism should be central to the analysis of lack of success and achievement of African Americans (Closson, 2010).

In addition to the pedagogy of the classroom, researchers have argued that an integration between instruction and support services is necessary for success of all students, especially basic skills students and students of color. The RP Group (2007) argues that counseling is an essential component of basic skills programs, and that counselors must work alongside faculty members to ensure that students get consistent and frequent academic advice, rather than just ad hoc advising, as is still usually the case. Frost et al. (2010) 
argue that the "curricular and co-curricular" must be in partnership in order for student success to be enhanced. Further research needs to be conducted on the ways in which critical race theory and culturally responsive pedagogy are present in such partnerships.

\section{Justification and Significance}

Researching programs that target the success of African American college students is important for a number of reasons. The economic impact of low college success in the African American population is causing an economic gap in our country between the "haves" and the "have-nots" (McKinsey, 2009). Since college success is generally seen as necessary for economic mobility, the lack of success for African American college students is negatively impacting the African American community. According to the National Center for Education Statistics (2010), the median salary in 2009 for a person with a bachelor's degree is $\$ 46,930$, whereas a person with only a high school diploma is $\$ 27,380$. This large discrepancy indicates that there is a significant economic advantage to earning a bachelor's degree; therefore, in order for there to be economic opportunities for African American students, the educational system needs to do a better job of graduating these students from college.

In addition, this lack of success is having an economic impact on the country at large. Again, according to McKinsey (2010), the country's gross domestic product (GDP) is negatively affected by the achievement gap between black and white students. It is estimated that about two to four percent of the GDP is lost due to the lack of education attainment by blacks (and other minorities) in this country.

Very little research has been conducted on the various models in place at community colleges with African American learning community programs. While there have been studies on other programs targeting underrepresented students, such as Puente (Rendón, 2002) and Extended Opportunities, Programs \& Services (Scott-Skillman, 1992), there are few studies on programs that specifically target the success of African American college students, with the exception of those studies conducted at Historically Black Colleges \& Universities (HBCUs). Thus, this research will be breaking new ground as it describes the pedagogical components and integration of support services of a program specifically designed for African American community college students.

Finally, in addition to the implications this research has for educational equity issues, the study could also have an impact on colleges across the nation. This study identifies the key underlying pedagogical and support strategies in learning community classrooms that can be replicated on a large scale. Thus, colleges and instructors interested in increasing the success of all students could potentially adapt the pedagogical practices of these instructors so that all students, regardless of race or ethnicity, can succeed. In addition, colleges can potentially adapt the integration model to create a connection between pedagogy and support services to further enhance student success.

\section{Design and Methodology}

A case study methodology was used to explore the research questions, keeping in mind that a case study method is appropriate for understanding a real-life situation in depth and within the contextual conditions of the situation (Yin, 2009). In keeping with the case study design, evidence was collected from multiple sources: semi-structured interviews with instructors in the learning community classrooms; interviews and follow-up focus groups with students; direct observations of classroom teaching; and physical artifacts gathered from the instructors. Of the three instructors observed and interviewed, two were African American and one was white. Of the 19 students interviewed individually and in focus groups, 16 selfidentified as African American.

The use of these multiple sources of data provided the opportunity to develop a "convergent line of inquiry" (Yin, 2009, p. 115). In triangulating the data employing this methodology, for example, it became evident how culturally responsive pedagogy played out in the learning communities and how students perceived its use in the classroom. Convergence of data is a major strength of conducting case study analyses (Yin, 2009). The use of multiple sources provided the opportunity to triangulate the data and to determine from a variety of perspectives the ways in which the pedagogies, teacher behaviors, and integration of instruction and student services impacted the students. 


\section{Role of Researcher}

As an English instructor in a community college for 20 years, I am a practitioner/researcher. My experience in the classroom and my extensive experience with learning communities targeting underrepresented groups provided me with an easy rapport with the instructors I interviewed. I did not interfere in the classroom sessions in any way; however, my extensive experience as a classroom instructor gave me the ability to listen not only to what the teachers said, but also to interpret how they interacted with the students. I had no previous contact with the instructors or the students before conducting the study.

\section{Setting and Sample}

Currently, ten of the 27 California community colleges with African American learning community programs are located in the Bay Area. To determine which colleges to include in the study, a purposive sample of colleges was selected based on local college data that shows the programs to be successful in terms of helping African American students succeed in developmental and college-level classes. Capstone College was chosen because it has the longest-running learning community, which began in 1994. In addition to Capstone, the programs at Landscape and Silicon Colleges were chosen for their long-standing, successful programs targeting African American students.

In addition to their successful student outcomes, the three colleges were chosen for inclusion in this study for their variety of characteristics. Landscape College is a medium-sized suburban community college with a low percentage of African American students. Capstone College is a medium-sized college located in a densely populated area with the percentage of African American students equal to that of the surrounding area. Silicon College is a small community college located in an urban area. These colleges represent a solid range of community colleges in Northern California; therefore, the results of this study are likely to be generalizable to a variety of community colleges in California.

\section{Data Analysis}

To analyze the data collected, the interview questions were organized into specific categories, which helped in synthesizing the teachers'and students' ideas about different topics. Based on these specific categories, a coding system was developed (Bogdan \& Biklan, 2007) focusing primarily on the perspectives held by the teachers and students interviewed. The codes were developed along with the interview protocols and thus could be described as "selective coding" (Glaser \& Strauss, 1967). In the same way, the observation notes for the classroom observations were similarly divided into topics that were coded and organized. An Excel spreadsheet, developed by Dr. David Wick (2011) was used to organize the data, enabling the researcher to code and search the specific themes.

The data were systematically analyzed as follows. The researcher conducted: 1) an "intelligent reading" of the transcripts to get a holistic sense of the data; 2) a "microanalysis" or line-by-line reading of the transcripts togain an understanding of the relationship between the codes; and 3) a "constant comparison" process to refine the codes chosen. Using notes from the observation, incidences of culturally responsive pedagogy in each classroom were charted. Subsequently, responses to questions about culturally responsive pedagogy were compared between the students and teachers, and the observations of such pedagogy were compared to students' and teacher's responses.

Because the study is a cross-case analysis, a technique that Yin (2003) calls "cross-case synthesis" was used. Data from the three colleges were aggregated as outlined above. A "word table" (Yin, 2003, p. 158) to synthesize the data across the colleges was used to discover patterns among them. For example, the topic of "nurturing relationship" emerged from the interview protocols of the individual teachers. A generalization about the presence of such a pedagogical strategy in the three programs could then be made.

\section{Findings}

Learning Community Pedagogical Practices

To think about pedagogy is to consider two aspects of teaching: the methods or strategies that a teacher uses in the classroom and the behaviors of the teacher him/herself. It is often difficult to separate methods from behaviors and attitudes because how a teacher acts is linked closely to the strategies she chooses. For example, if a teacher is a proponent 
of active learning, she is often moving around the classroom being physically active herself. Likewise, a teacher who practices authentic pedagogy is likely to reveal aspects of his own humanity to the students. For the purposes of this study, the teaching techniques the teachers chose are analyzed separately from their specific behavioral characteristics. This is an important separation because the personas teachers present in the classroom add a different dimension to the class from the teaching practices they employ.

\section{Authentic Pedagogy}

Cranton and Carusetta (2004) define authentic teachers as "being genuine, showing consistency between values and action, relating to others to encourage their authenticity, and living a critical life" (p. 7). What this definition highlights is the personhood of the teacher in the classroom. Authentic teachers behave in a manner that integrates their values with their teaching methods.

The English teacher from Capstone College very much integrated his values with his teaching. In his interview, LaSalle described what he does as "live learning" as in learning that is alive.

There's lots of ways to express "live learning," but some of the basics I guess are that you walk into the classroom, you have something in mind basically ... but you don't make the meaning. They make all the meaning. And you facilitate the meaning, but if you want to up it because you think it would be more abstract, more translate to academic work, or just more get closer to their pain, then you can up it, but it's organic because it's right in what they're talking about.

What LaSalle is describing here is a type of improvisation that a teacher who actively engages his students must be willing to participate in. In keeping with the notion of improvisation, LaSalle took his cues from the students and spontaneously changed his agenda to fit their needs. By its very nature, improvisational teaching requires an integration of the teacher's philosophy of teaching and his knowledge of the subject matter. It is this integration that creates the authenticity so apparent in the classrooms of these African American learning communities.

The idea of full disclosure was apparent in the math class taught by Sue Davis at Landscape College. In outlining the content of the upcoming test, the instructor listed exactly what she expected her students to know:

I gotta stick some equations on there. Gon' stick some factoring on there. Gon'stick some parabolas on there. Some factoring and some quadratic formulas ... Gon' have a couple word problems

Not only is the teacher's agenda transparent, she purposively designed assessments that allow students to learn and to apply the concepts in authentic ways.

To illustrate that her teaching approach is grounded in a philosophical belief, Sue Davis describes her teaching strategies:

I will take the mathematics and I will not put it in mathematic jargonese. I will explain it because my purpose is for you to understand ... I can train a monkey to do something, I want you to understand. This ain't about coming in here and passing quizzes. This is about understanding mathematics so when you walk out of here, you'll know what you're doing.

And the students respond positively to this full disclosure. As Tre said:

Ms. Davis is the truth, I tell you. Ms. Davis, she's the truth. I mean she's one of the hundred percent teachers that are real on campus, and she'll tell you if you don't get yourself right, you're not going anywhere.

In this heartfelt description of Ms. Davis as "the truth," Tre indicated that he trusts his teacher to be honest with him no matter what.

Echoing the idea of honesty, Tanaya describes the honesty she gets from her English teacher at Capstone College: 
LaSalle is kinda like the best part of [the program], just the way he teaches ... especially 'cause he's Caucasian 'cause he tells the truth. You know how some people they'll tell you something, but they're not telling the full story? LaSalle gon' tell you the full story.

In this comment, Tanaya expressed her trust that Mr. LaSalle will be honest "especially 'cause he's Caucasian." Tanaya is one of two students who mentioned Mr. LaSalle's racial identity as they described their experiences with him. Both students who referred to LaSalle's being White mentioned his race in the context of discussing their trust in him. In his interview, Dashawn described his skepticism about being taught by a white teacher:

When I first met him, I was kind of cautious about him because you know he was a white male teacher in an African American class, and the first thing that hit in my head was "What can he teach me?"

LaSalle's authenticity, his fundamental belief in his students, turned Tanaya and Dashawn from skeptics into believers.

Teachers in this study are strategic in their thinking about African American students; they are aware of their students' cultural differences and their differing needs. Within this context, the teachers must devise ways to engage African American students with substantive ideas. As a white man, the English teacher at Capstone certainly is aware of the cultural identity his students bring to the classroom, and he uses his knowledge of them to engage them in discussions about African American writers and issues. Thus, despite his identity as a white man, the students trust his authenticity as a teacher and as a human being.

\section{Othermothering}

In summarizing the tradition of othermothering in the African American community, Guiffrida (2005) traces the practice to the first African American slave communities wherein women assumed the role of mother figure for children whose fathers were absent and/or whose mothers had died or had been sold. This tradition of taking on mothering responsibilities continues in African American schools and historically Black institutions where teachers are interested in more than just the academic development of their students but their emotional and spiritual developments as well.

The students in this study described the teachers' demanding natures as evidence that they have the students' best interest at heart. Guiffrida (2005) calls this quality "othermothering" taken from the traditional African American role of a mother figure who takes over the role and responsibilities of a mother. A student at Landscape College, Sonny understands the approach his teacher takes because he has lived it. He explains:

Ms. Davis really isn't for everybody. You gotta be able to handle a lot. She's tough, but you gotta know how to deal with those type of personalities ... they'll push me, just like a parent. They push you to do harder, to do better."

In a particularly poignant moment in an interview session, Sonny describes the fundamental quality of his learning community teachers:

What makes them different from every other staff and faculty is the heart for the kids. ... The heart makes the difference that will make the kids do the extra amount because they know at the end of the day ... they care for us!

All of the teachers interviewed expressed in their own way their deep care for their students as whole people, not just their academic development. Sue Davis describes the pride she feels in seeing students move from being scared to confident in their math abilities:

And I mean I swell up sometimes thinking about the number of students who walked in there, head held down, scared as hell to do anything in mathematics...And it's gotten to the point where they've forgotten their fear. I gotta get them to the point where [they] don't accept anybody else's answer, go try to figure 
it out for yourself. And believe it or not, the next thing I hear, "I want to be like Ms. Davis." No, girlfriend, you don't want to be like me. You want to be like you. Take that confidence and run with it.

Her methods may be unorthodox; it may be true that, as she says, "If you can survive Ms. Davis, you can survive anybody on this campus." But underneath the "hittin' and cussin' and fussin"' is a teacher who truly cares that her students succeed. And she is maternally possessive of these students. "They're my kids," she says. "That's it."

Rob LaSalle expresses his care for his students when he describes the necessity of education for these students:

I think that for me, the African American students...it's very, very palpable what's at stake. I could tell you the stories of those students in that classroom and the proximity to jail, homelessness. I have maybe two middle-class students in there, and the rest are just absolutely on the edge. And that makes you a different kind of teacher. You know your pedagogy changes. It's not just your heart, but your pedagogy.

The teachers and counselors care for these students, and the students not only see it and appreciate it, the care motivates them to succeed. In the focus group, Calvin remarks:

And so when my teachers would kind of push you know, "Ok we want you to pass and this is what you need to do." And it kinda showed a passion for our success, which kinda fueled my passion for my success.

What these students are responding to is the teacher's genuine care for them, not just as college students, but as human beings as well. When the students in this study say that their teachers actually respond to them and that they are "always there" for them, the students are describing a care for the whole student that is created, cultivated, and maintained in a concerted manner by the teachers who love the students as their own.

\section{Warm Demander}

The students in both the interviews and the focus groups report that while their teachers in the learning communities are caring and focused on their success, the teachers are also quite demanding in their expectations of the students' success. Ware (2006) uses the term "warm demander" to describe the pedagogical stance taken by teachers on African American students. Describing this style as a "tough-minded, no nonsense approach" (p. 436), Ware points out that students perceive this style as evidence that the teacher cares deeply about them.

The math teacher at Capstone College is a prime example of the warm demander personality. Throughout the class session observed, she laughingly chided the students when they hesitated on answers she thought they should know. When telling the students that their tests were due on Tuesday, the math instructor said, "I don't want nothing late, and don't be emailing me at the last minute talking about my car broke. Leave the car, bring my test. I'm serious, ok?" Her use of African American Vernacular English ("don't want nothing") gives her a connection to the students, but her insistence that they perform no matter what illustrates her demanding nature. She refuses to believe that her students could not perform, so they did.

A student at Capstone College, Calvin stresses that the learning community teachers demand exceptional performance from the students. He describes his teacher this way:

I think he would prefer that we ask questions rather than not ask anything at all ... 'cause he talked to everybody yesterday about how he feels like certain people in the class aren't necessarily chasing knowledge ... just like how a lot of us are just going through the motions in the class instead of really trying to get more than just what he's trying to teach us, but to also get something that we can carry on in life.

In Calvin's experience, the teacher wants the 
students to "chase knowledge" not just be passive learners. A student from another college, Astra, remarks that being pushed hard has positive results on her achievement:

Sometimes she'll kind of like yell at me like, "Oh you're not doing good," and then I'll be like, "Oh I can do better." Then I do better, or I'm trying and then she'll see that and she'll kind of like ease off of me, but more than half the time she helps me push myself to levels I didn't think I could get to sometimes.

All of these students cite their teacher's harsh manner and demanding nature as difficult, hard to get accustomed to, but essential to their academic achievement. The motherly nature of the teachers in this program convinces the students that the instructors care; the demanding, harsh language compels them to succeed.

\section{Culturally Responsive Pedagogy}

Researchers have long noted the connection between students' embracing of racial identity and academic performance (Carter, 2008; Carter Andrews, 2009; Fife, Bond, \& Byers-Winston, 2011; Fries-Britt \& Turner, 2002; Palmer \& Gasman, 2008). According to these studies, validating a student's identity, including his or her racial identity, is an important step in making that student feel competent to succeed in college. Gloria Ladson-Billings's seminal work (1995a) and (1995b) lays out the precepts of culturally relevant pedagogy: the achievement of educational success on the part of African American students through the development and maintenance of their cultural competence. Gay (2010) best describes culturally relevant pedagogy as validating and affirming. By acknowledging the legitimacy of the cultural backgrounds of different ethnicities, students are to connect what they learn in school with what they live at home. Culturally responsive pedagogy uses a wide variety of teaching strategies for connecting to a variety of learning styles. Finally, by incorporating multicultural information in all the subjects taught, culturally responsive pedagogy teaches students to value their own and each other's cultural heritages.
The students in this study were recipients of culturally responsive pedagogy, and they speak of how the learning community helped them deepen their understanding of themselves as African Americans in terms of understanding their history and strengthening their sense of racial identity.

\section{Understanding History}

One means by which the programs helped the students understand themselves as African Americans was the way the classes taught them about African and African American history. The students learned about important contributions African Americans have made to American history, and this knowledge gives the students a sense of pride in their heritage.

As Chantel says of her classes in the program:

It's based on African studies. So there's a lot of things that I did not know about that I learned in college. Because in my history books, there's just this big gap that I didn't understand ... and now I do.

Chantel's statement reveals that her understanding of African American history has become a part of her. Dashawn also discusses how the topics discussed in the learning community affected his understanding of his racial background:

Because it taught me a lot about my background and my history. And a lot of things that I didn't know that I was able to learn about myself and to where that I'm just as equal as everybody else ... So that helped me give me a little boost to my self like about, "OK if I really have that desire, then I really can. All I gotta do is do it."

From Dashawn's perspective, it is clear that his understanding of African American history has increased his self-confidence. When he says, "All I gotta do is do it," he illustrates how a student's understanding of the past can affect his present. What all of these programs have in common, then, is that they use African American writers and/or topics for the students to read and respond to. The use of culturally responsive 
pedagogy is a primary goal for these programs.

More important than the use of such materials, however, is the students' reactions to this curriculum. While some students mention that the assignments are difficult, most of the students express a connection to their identity, a deepening of their understanding of themselves as African Americans. In the African American learning communities in this study, the African American culture is emphasized even in classes that may not seem lend themselves to cultural perspectives, such as mathematics courses. By including their culture in the curriculum, the teachers send the students the message that their history - and by extension, they count.

\section{Culturally Responsive Pedagogy and Racial Identity}

Another positive outcome to culturally responsive pedagogy is the connection to identity and the strengthening of African American identity. One outspoken student in this study, Sekena, explains:

[The program] helps you broaden your mind. It's just like you can do anything; you can be anything. That's just what this program makes you feel like.

When Sekena talked about being a Black female in society, she discussed her connection to the larger community of African Americans and how this connection makes her feel "like you can do anything."

In describing what it's like to be in a program made up of primarily African American students, Manny says:

But I see all these people from backgrounds, hard backgrounds, some you know cool backgrounds, and seeing them all come together and doing good, helping each other, assisting each other, it feels good to be African American and knowing I have other people, peers, especially peers who come from all kinds of backgrounds doing good and trying to do good.

In discussing the diversity of the African American community, Manny appreciates how the program has given him examples of success across the spectrum of the community. In a particularly eloquent statement, Manny went on to explain the impact of a particular piece of culturally responsive pedagogy. Manny says:

It showed me how unfair the justice system is and how unfair the world is. When you don't experience things like that, you think the world is fine, but when you see somebody who's coming from your same background experience something like that and not be treated fairly, it makes you think that could happen to anybody. That coulda been me or my dad. so those assignments like they really change my perspective on who I am and where I come from and how the world looks at me.

In this quote, Manny recognizes himself in the literature; he understands that he or someone he knows could have been the victim of racial injustice. And in connecting with the curriculum, he found his voice.

Another student Malik expresses his experience with the learning community as finding a place where he belongs:

Comfort. I say comfort just because you can sit in class and you can sit in two class periods, you can sit in the morning class, you can sit in your own class and you can sit through the tutoring process, you're just there the whole day and it just makes you feel like, "Ok this is where I want to be." This is your stress level away from the outside world.

From these comments, it's clear that Malik has found his place at the college. He is at home with the classes, the other students, and the learning environment.

The findings in this study correlate with those of the body of literature on culturally responsive pedagogy and the developing of racial identity among students. This study illustrates from the students' perspective just how tight a connection there is between curriculum and identity.

\section{Culturally Responsive Pedagogy and Finding a Voice}

Another way in which culturally responsive 
pedagogy is said to help students of color is by helping them find a voice in the classroom and in the academy. In Teaching to Transgress (1994), bell hooks sees validating student voices as empowering the students' presence in the class. In her insistence on listening to the voices of students, hooks encourages teachers to cultivate their students' voices so that the students themselves can serve as challenges to the system that seeks to silence them.

Echoing the idea of deep understanding of racial identity, Sukutai describes the culturally responsive pedagogy as empowering her to succeed:

It makes me feel powerful. It makes me feel like we really have to stand up and do something. Because the stories we read were like kids our age that really stood up back in the day and we could still do the same to make it better.

A student in the same cohort, Chantel, talks about how the culturally responsive assignments helped her find her voice:

We had to relate the book, it was about the Little Rock Nine kids, to our experiences with schools. And it's different when you have those thoughts in your head, but when you lay them out, and you figure out how to format things right, it's just it's nice to see that.

Carmen describes her struggle with writing and how an assignment on a Boots Riley poem helped her discover her ideas:

Well at first I was like "oh my gosh, I don't want to do this." But then like once you think about it, you're like "Ok I understand it. I do want to write." And once you start writing, you don't want to stop. So I think the essay was like two pages, and he said don't go above that. I tried not to, and it was so hard because you want to keep writing.

It is the newly found sense of confidence that is apparent here. Carmen and the rest of the students see themselves as having a voice, that they have something to say, and that they are worthy of being listened to.

When asked about the most valuable part of the program for him, Dashawn reflects much of what the other students say:

The most valuable thing about [the program] is that I was able to be successful. I was able to express my opinions. I was able to ask questions ... so it just opened up a whole lot of different views and it was like my stairway to success. When I first got to English, a 2-page paper made me shiver. And now I got an 8-page paper [assignment] and I said, "Oh that's it?" And I had written a 10-page paper and had to cut it down because I wrote too much.

Dashawn has been transformed from a student who dreaded even the smallest writing task to a student who is not fazed by a lengthy assignment. He has truly found his voice.

In her study on the relationship between racial identity and school achievement, Carter (2008) describes how connectedness to the Black community and awareness of racial discrimination prove significant to the development of Black students' critical race consciousness and shape their attitudes about the usefulness of schools. The students in her study believed in the positive outcomes of school because of their positive racial self-conceptions, belief in their abilities to be successful, and critical race consciousness. The implications of Carter's study and of the current study are clear: the more racially developed the identities of students are, the more likely they are to succeed in school.

Integration and "Intrusion" of Instruction and Student Services

Since the seminal collaboration between the American Association for Higher Education, the American College Personnel Association, and the National Association of Student Personnel Administrators (1998), colleges have been considering ways of integrating academics and student services in order to enhance student learning. The learning 
communities studied here appear to put this theory of integration into practice.

The counseling, financial aid, and tutoring services at the colleges I observed are what the student services field calls "intrusive services." They are intrusive because they are not simply offered to students; rather, both the instructors and counselors in the programs require that the students use the services. At Landscape College, the counselor herself makes the counseling appointment for the students; the teacher requires that the students submit a progress report detailing the current grades in all their classes and personally supervises tutorial sessions five days a week. At Capstone College, the teacher uses class time to inform students of available services. At Silicon College, the students take college tours as a group, have academic counseling sessions, and regularly attend required math tutorial sessions. All the instructors integrate the services into their classrooms, taking instructional time to introduce the students to the services and to require that the students use them. Bringing the services to the students, taking out instructional time to present services, and requiring that students use the services are the keys to intrusive services.

The important aspect to the integration of student services and instruction is that both instructors and counselors think that achieving student success is a joint effort. No one creates a line of demarcation that indicates a separation of duties; both feel responsible for the holistic development of the students.

\section{Implications for Community College Policy and Practice}

Structural Changes

The findings from this study suggest that success in learning communities is reliant upon a new structure of pedagogy and classroom experience. Thus, it is recommended that colleges consider structural changes to the ways they offer classes and programs.

In particular, instructors and student services staff should reconsider their roles, and that these new roles be supported by the administration of the institution. In this study, the students succeeded in part because they used the support services available to them, specifically financial aid and tutorial services. They were made aware of these services because both teachers and counselors were willing to take on each other's roles. Teachers used class time to discuss support services, and counselors visited the classroom to meet individually with students. Such a reimagining of traditional roles could be replicated by the institution as a whole to encourage collaboration among instructional programs and student services across campus.

Another structural change would be to reevaluate curriculum development and design. Traditionally, instructional faculty members are solely responsible for curriculum development. Including student service professionals in curriculum design would ensure the education of the whole student instead of merely focusing on the student's academic development.

Finally, colleges need to consider how to offer students important services in one convenient location. One of the reasons the students in the learning communities so effectively used the support services is that the services were accessible and intrusive. Colleges should, therefore, consider ways to ensure that students who need such services have easy access to them; indeed that they are required to access them. From this study and others, developmental students and students of color are in the most need of student support services. Therefore, colleges should commit themselves to requiring these students to use these services, even if it means making the difficult decision to limit access to services for other students.

\section{Race-Conscious Programs}

Institutionalized racism has led teachers to have negative perceptions about the abilities of their African American students. Costner, Daniels, \& Clark (2010) surveyed over 200 community college faculty and found that while the faculty expressed willingness to teach African American students, they were not willing to use teaching strategies that have been found to increase the success of African American students. In fact, the instructors were overwhelmingly predisposed to colorblind attitudes towards their students, an attitude that Irvine (1990) describes as "cultural aversion." According to Irvine, cultural aversion is the reluctance of teachers and administrators to discuss race and race-related issues, such as ethnicity, culture, prejudice, equality, and social justice. If we are averse 
to talking about our students' cultures, then we are averse to our students.

Therefore, it is recommended that our institutions re-evaluate the colorblind policies that have been in place and start to implement race-conscious programs, such as the learning communities described in this study. Institutional leaders should acknowledge that race and racism are at the center of the achievement gap between African Americans and their White and Asian counterparts. Once we acknowledge the problem, we can begin to put programs into place to solve it.

Instructional leaders, both faculty and Academic Senate leaders, must also re-evaluate their colorblind policies. To pretend that we do not see color, to claim that we treat every student the same, is to ignore the different needs of our racially mixed student population. Treating students equally is not the same as treating students the same. We should not assume that a "one size fits all" approach to education will serve all students well.

Another key finding from the studies shows that the racial component of the learning communities was a key part of the students' success. The culturally responsive pedagogy and the sense of community gained by being in a classroom of majority African American students gave the students in this study a deepened sense of their identity as African Americans. They felt proud of their history, and they felt accountable to and for the other students in the cohort.

It is for this reason that it is recommended that all colleges implement race-conscious programs for their African American and Latino students. It is clear that racial identity matters in terms of the support students receive from ethnic-specific programs. When students feel that their racial identity is validated, they reflect a strong engagement with the cohort and, by extension, with the college. Engagement and retention literature indicates that such connections result in higher persistence and success rates among students of color.

In addition to programs that target specific ethnic groups on campus, it is recommended that culturally responsive pedagogy be integrated into the curriculum of all courses. African American and Latino studies courses should be offered to students early in their educational careers. Instead of these courses serving as electives that students take at the end of their coursework, students should take these courses at the beginning of their studies so they benefit from the identity development these courses offer.

\section{Recommendations for Future Research}

As a researcher, I am aware of the limitations of this study. The population sample was relatively small (19 students from three California colleges) and the students themselves included only those students who had succeeded in the learning communities. Future studies, then, could focus on a larger selection and wider diversity of students by including part-time students and students who dropped out of the program before finishing. The students in this study were chosen by the teachers and counselors in the programs, often as convenience samples from students available at the time. Further research could be conducted on a more carefully selected sample of students.

Another area for further research is to study how long the impact of the learning communities lasts for students. In other words, what happens to students once they leave the learning community and begin taking classes by themselves in other parts of the college? Do they transfer to a four-year institution, and what happens to them after that? An ethnographic study could be conducted to see how the cultural capital and identity development the students gain from the African American learning communities translates into future academic success for the students.

Such an ethnographic study would also help answer the question: how long should a college nurture a student before it expects the student to be fully selfsufficient? It would be interesting to know if the yearlong program of building self-confidence and attaining academic and social integration is sufficient to help the students overcome the obstacles they continue to face throughout their college careers.

\section{Reflections}

As I consider what I have learned from this project, I reflect on the following topics: (a) race and teacher biases; (b) re-imagining the roles of instructional and student services personnel; and, (c) the lasting impact of the experience on students. 


\section{Race and Teacher Biases}

Again looking at the problem of African American student retention through a racial lens, I wonder whether we can require teachers of all ethnicities to care about African American students the way they care about other students. As our society is paradoxically getting more diverse and more segregated than ever, how do we get teachers, administrators, and college staff to set their stereotypes aside to educate a population they may not be familiar with? Beverly Daniel Tatum (2007) refers to unconscious racism in terms of living in a smoggy city. When you live in smog, you breathe dirty air. So it is with race and racism, she says. When you live in a racist society, you can't help but internalize some of that racism. So if we truly want to look at how to teach our teachers to retain African American students, we have to first ask them to see their own place in this smoggy city, to examine their unconscious biases, and then to understand and truly care for their students of color.

\section{Re-Imagining Traditional Roles}

Here I offer some suggestions for redefining the roles of community college instructors and student services personnel. Four-year institutions have longstanding traditions of having faculty serve as academic advisors for students. Not only does this academic advising help students and faculty develop relationships outside the classroom walls, but such advising also instills a sense of responsibility for student success on the part of the faculty. While I understand that asking community college instructors to be academic advisors has labor negotiation implications, it is important that teachers be pushed to think about students outside of the traditional relationship.

I also argue that student services personnel should be rethinking their own traditional roles. Perhaps counselors should no longer offer 20-minute appointments on a first-come, first-served basis. Perhaps instead selected students should be given longer individual appointments while traditional students be given group-counseling appointments. Perhaps, too, counselors should be cross-trained in giving advice on matters other than academics, for example, financial aid counseling for students. Finally, I suggest that the traditional model of funding for student services needs to be re-evaluated. If counselors do begin to offer group-counseling sessions, perhaps these sessions could be weekly student contact hour (WSCH)-generating so that student services budgets are not constantly at the mercy of instructional budgets.

In the words of Tavis Smiley, an African American talk show host and political commentator, African American students are "too important to fail." The student voices in this study convince us as educators to pay particular attention to the ways our structures can change to help our students succeed. I would argue that it's not enough for us to simply care about the students we serve; we need to be willing to change some fundamental assumptions about the ways we create curriculum, structure class time, and offer support services to students who need them. Without such changes, we are simply conducting business as usual and achieving the same disheartening results.

\section{About the Author}

TESS HANSEN, Ed.D., is an English instructor at Foothill College. Her area of interest is community college success for underrepresented students. In particular, she is concerned with developmental student success, and the pedagogical and institutional strategies that increase student achievement.

email: hansentess@foothill.edu 


\section{REFERENCES}

American Association for Higher Education, American College Personnel Association \& National Association of Student Personnel Administrators. (1998). Powerful partnerships: A shard responsibility for learning. Washington, D. C.: Authors.

American Council on Education. (2010). Minorities in Higher Education 2010: Twenty- Fourth Status Report. Washington, DC: American Council on Education.

Anzaldúa, G. (1987). Borderlands/La frontera: The new mestiza. San Francisco: Spinsters/Aunt Lute.

Bensimon, E. M. (2005). Closing the achievement gap in higher education: An organizational learning perspective. In A. Kezar (Ed.), Organizational Learning in Higher Education (pp. 131). San Francisco: Jossey-Bass.

Bogdan R. C. \& Biklen, S. K. (2007). Qualitative research for education: An introduction to theories and methods (5th ed.). Boston, MA: Pearson.

Braxton, J. M., Hirschy, A. S., \& McClendon, S. A. (2004). Understanding and reducing college student departure. San Francisco: Jossey-Bass.

Braxton, J., Jones, W. A., Hirschy, A. S., \& Hartley III, H. V. (2008). The role of active learning in college student persistence. New Directions for Teaching and Learning, 115, 71-83.

Braxton, J. \& McClendon, S. (2002). The fostering of social integration and retention through institutional practice. Journal of College Student Retention, 3(1), 57-71.

Carson, L. (2009). "I am because we are": Collectivism as a foundational characteristic of African American college student identity and academic achievement. Social Psychological Education, 12, 327-344.

Carter, D. (2008, Winter-Spring). Cultivating a critical race consciousness for African American school success. Educational Foundations, 11-28.

Carter Andrews, D. J. (2009). The construction of Black highachiever identities in a predominantly White high school. Anthropology and Education Quarterly, 40(3), 297-330.

Closson, R. (2010). Critical race theory and adult education. Adult Education Quarterly, 60(3), 261-283.

Costner, K., Daniels, K. \& Clark, M. T. (2010). The struggle will not continue: An examination of faculty attitudes toward teaching African American students. Journal of Black Studies, 41(1), 40-55.

Cox, R. (2009). The college fear factor: How students and professors misunderstand one another. Boston, MA: Harvard University Press.

Cranton, P. \& Carusetta, E. (2004). Perspectives on authenticity in teaching. Adult Education Quarterly, 55(1), 5-22.

Daniel Tatum, B. (2003). "Why are all the Black kids sitting together in the cafeteria?" and other conversations about race (Rev. ed.). NY: Basic Book.

Darling-Hammond, L. et al (2008). Powerful learning: What we know about teaching for understanding. San Francisco, CA: Jossey-Bass.

Delgado, R., Stefancic, J. (2001). Critical Race Theory. New York: New York University Press

Engstrom, C. \& Tinto, V. (2007). Pathways to student success: The impact of learning communities on the success of academically under-prepared college students. Unpublished manuscript, The William and Flora Hewlett Foundation.

Fife, J. E., Bond, S., Byars-Winston, A. (2011). Correlates and predictors of academic self-efficacy among African American students. Education, 132(1), 141-148.

Fries-Britt, S. \& Turner, B. (2002). Uneven stories: Successful Black colleges at a Black and White campus. Review of Higher Education, 25(3), 315-330.

Frost, R.A., Strom, S. L., Downey, J., Schultz, D. D. \& Hollard, T. A. (2010). Enhancing student learning with academic and student affairs collaboration. The Community College Enterprise, Spring 2010, 37-51.

Glaser, B. \& Strauss, A. (1967). Discovery of grounded theory: Strategies for qualitative research. Chicago: Aldine.

Guiffrida, D. (2005). Othermothering as a framework for understanding African American students' definitions of student-centered faculty. The Journal of Higher Education, 76(6), 701-723.

Guiffrida, D. (2006). Toward a cultural advancement of Tinto's theory. Review of Higher Education. 29(4), 451-472.

Hooks, B. (1994). Teaching to transgress. New York: Routledge. Irvine, J. J. (1991). Black students and school failure. Westport, CT: Praeger.

Johnson-Bailey, J, \& Lee, M, (2005), Women of color in the academy: Where's our authority in the classroom? Feminist Teacher: A Journal of the Practices Theories and Scholarship of Feminist Teaching, 15(2), 111-122

Lopez, G. (2003). The racially neutral politics of education: a critical race theory perspective. Educational Administration Quarterly, 39, 68-94.

McKinsey \& Company. (April, 2009). The economic impact of achievement gap in America's schools. Social Sector Office.

McHugh Engstrom, C. (2008) Curricular learning communities and unprepared students: How faculty can provide a foundation for success. New Directions for Teaching and Learning, 115, 5-19.

Palmer, R. \& Gasman, M. (2008). "It takes a village to raise a child:" The roe of social capital in promoting academic success for African American men at a Black college. Journal of College Student Development, 49(1), 52-70.

Rendón, L. I. (2002). Community college Puente: A validating model of education. Educational Policy, 16(4), 642-667.

Ross, T., Kena, G., Rathbun, A., KewalRamani, A., Zhang, J., Kristapovich, P., and Manning, E. (2012). Higher Education: Gaps in Access and Persistence Study. U.S. Department of Education, National Center for Education Statistics. (NCES Report No. 2012-046). Washington, DC: Government Printing Office.

RP Group. (2007) Basic skills as a foundation for student success in California community colleges. Sacramento, CA: California Community Colleges System Office.

Scott-Killman, T. et al. (1992). Student Services and Special Programs: A Report on Program Effectiveness. Retrieved from ERIC database. (ED351065).

Tavis Smiley Reports. (2011). Too important to fail: Saving America's boys. SmileyBooks.

Tierney, W. (1999). Models of minority college-going and retention: Cultural integrity vs. cultural suicide. Journal of 
Negro Education, 68(1), 80-91.

Tinto, V. (1975). Dropout from higher education: A theoretical synthesis of recent research. Review of Educational Research 45(1): 89-125.

Ware, F. (2006). Warm demander pedagogy: Culturally responsive teaching that supports a culture of achievement for African American students. Urban Education, 41, 427-456.

Wick, D. (2011). Study abroad for students of color: A third space of negotiating agency and identity. (Unpublished doctoral dissertation). San Francisco State University.

Yin, R. K. (2003). Applications of case study research (2nd ed.). Thousand Oaks, CA: Sage.

Yin, R. K. (2009). Case study research: Design and methods (4th ed.). Thousand Oaks, CA: Sage.

Yosso, T., Smith, W., Ceja, M., Solorzano, D., (2009). Critical race theory, racial microaggressions, and campus racial climate for Latina/o undergraduates. Harvard Education Review, 79, 659-681. 